LIGHT RAIL TRANSIT AS A TOOL FOR URBAN BROWNFIELD REVITALIZATION

by

Davin George Charles McCully

BA, Concordia University, 2013

A Major Research Paper

presented to Ryerson University

in partial fulfillment of the requirements for the degree of

Master of Planning

in

Urban Development

Toronto, Ontario, Canada, 2019

(C) Davin McCully 2019 


\section{Author's Declaration for Electronic Submission of a MRP}

I hereby declare that I am the sole author of this MRP. This is a true copy of the MRP, including any required final revisions.

I authorize Ryerson University to lend this paper to other institutions or individuals for the purpose of scholarly research.

I further authorize Ryerson University to reproduce this MRP by photocopying or by other means, in total or in part, at the request of other institutions or individuals for the purpose of scholarly research.

I understand that my MRP may be made electronically available to the public. 


\title{
LIGHT RAIL TRANSIT AS A TOOL FOR URBAN BROWNFIELD REVITALIZATION
}

(C) Davin McCully, 2019

Master of Planning

in

Urban Development Ryerson University

\begin{abstract}
In Europe and in North America, Light Rail Transit (LRT) is increasingly being seen as a viable and attractive transportation option which is not as cost prohibitive as heavy rail, yet carries more passengers and travels at higher speeds than traditional bus transit. Brownfield regeneration is at the forefront of urban land use policy, as cities try to reign in sprawl and address local economic, social, and environmental implications of such underused or abandoned sites. This paper will examine the relationship between the implementation of LRT in urban environments, and how that investment in transportation infrastructure affects the regeneration of urban brownfield sites. This will be achieved through the use of three urban case studies, each with subpopulations between 100,000 - 500,000.
\end{abstract}

Key Words: Light Rail Transit, Brownfield, Transportation, Sustainability, Urban Mobility, Urban Financing, Municipal Plans and Policies. 


\section{Acknowledgements}

I would like to acknowledge the people that helped me get to the finish line of this Master's program. First I would like to thank Professor Christopher De Sousa for being my supervisor and guiding me through this process. I would also like to thank Professor David Amborski for agreeing to be my second reader.

Further, I would like to thank my parents, Sandra, David, and Maureen for all their encouragement and support over the last two years. Without them, I would not be here today. I would also like to thank my partner, Chance, for being my rock and for keeping me sane through this process.

I would also like to thank Beth and Guillaume for graciously having me in their home when I traveled to London, UK, to experience the Tramlink LRT first hand.

Finally I would like to thank my classmates and the faculty in the M.Pl. Program at the School of Urban and Regional Planning. These last two years of been some of the most memorable and significant of my life, and they have all positively contributed to the person I am today. 


\section{Table of Contents}

Author's Declaration for Electronic Submission of a MRP ................................................ii

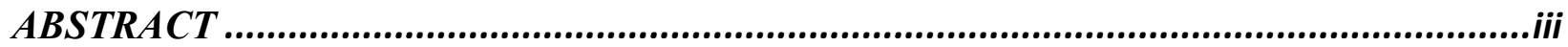

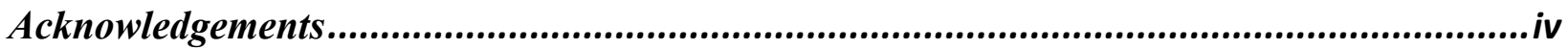

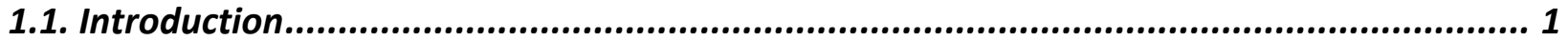

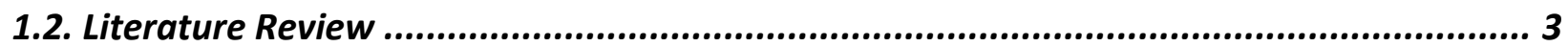

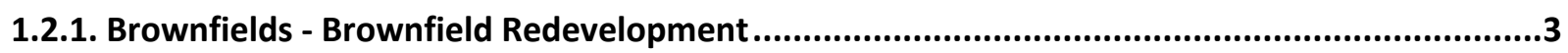

1.2.2. Transportation Infrastructure - Light Rail Transit ..................................................................5

1.2.3. Urban Redevelopment - Brownfields and Transportation.......................................................6

1.2.4. Sustainable Development - Transit and Land Use Integration.................................................8

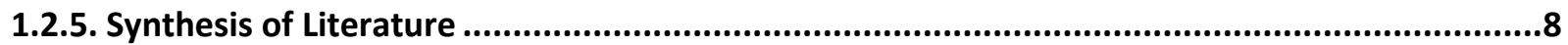

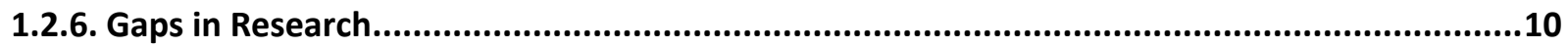

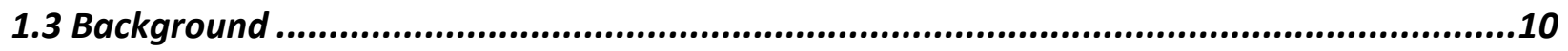

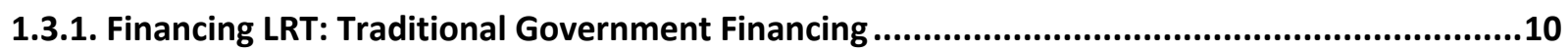

1.3.2. Financing LRT: Public-Private Partnerships ........................................................................11

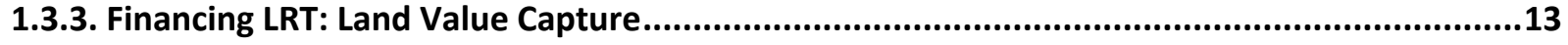

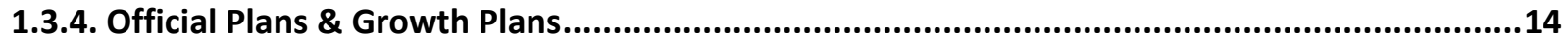

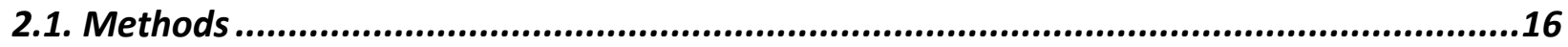

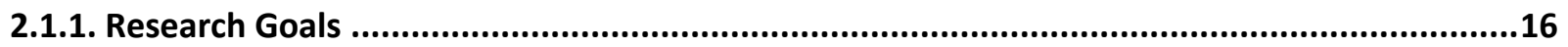

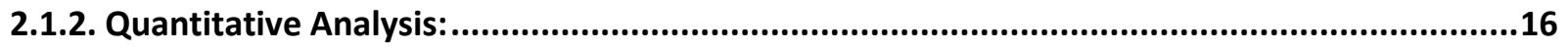

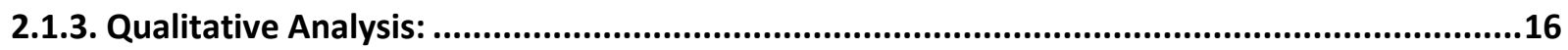

2.2. Rationale for Case Studies ........................................................................17

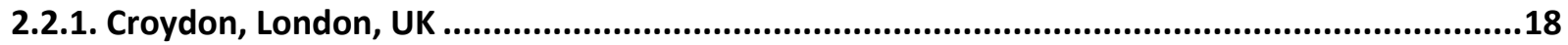

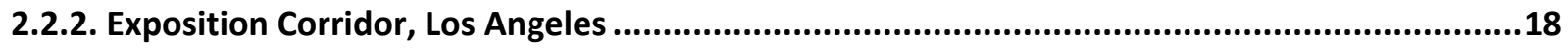

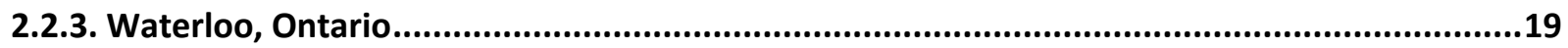

2.3 Methodological Limitations ............................................................................19

2.4. Realized Method of Analysis for Case Studies......................................................21

2.5. Expected Outcome/Contribution to knowledge and Policy..........................................22

3.1. Problem Investigation...................................................................................23

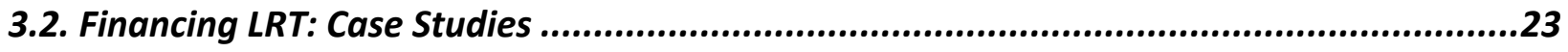

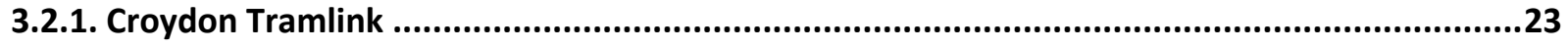




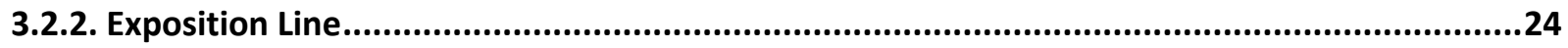

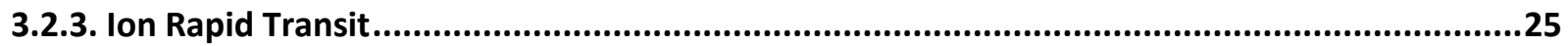

3.3. Policy, Planning, and Development Analysis: Case Studies ......................................26

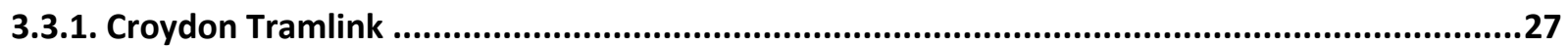

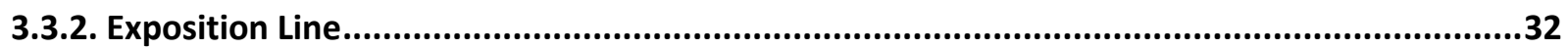

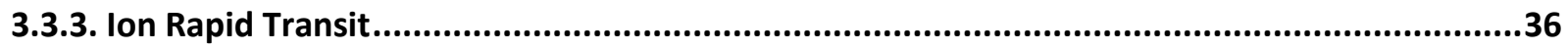

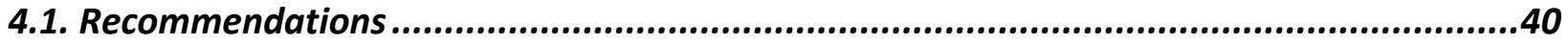

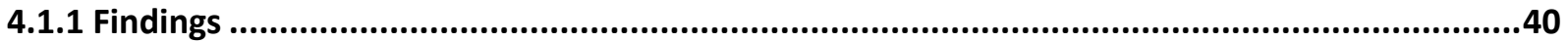

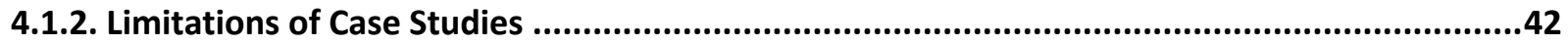

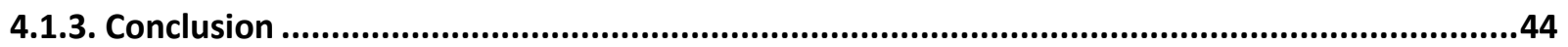

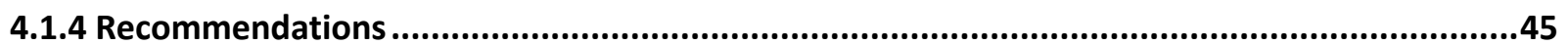

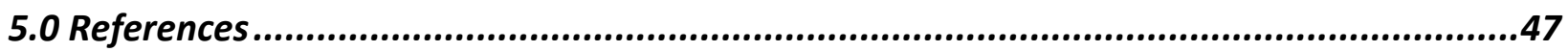

\section{List of Figures:}

Fig. 1 Central Croydon, case study context ma....................................... 26

Fig. 2 Croydon Opportunity Area, with Tramlink in Green................................ 26

Fig. 3 Location of Croydon within London, UK.......................................... 26

Fig. 4 Exposition Corridor, case study context map....................................... 31

Fig. 5 Exposition Corridor Boundaries.................................................... 31

Fig. 6 Metro Expo Line................................................................ 32

Fig. 7 Ion LRT, case study context map............................................... 36

Fig. 8 City of Waterloo, Station Area Planning........................................ 36

Fig. 9 ION Light Rail Transit Map (Kitchener to Waterloo)............................ 36 


\subsection{Introduction}

This paper sets out to explore the themes of transportation infrastructure and urban regeneration. Specifically, the intersection of light rail transit (LRT) and the regeneration of urban brownfield sites will be the major focus.

The relevance of this research lies in its implications for the two fields of study in which it inhabits. The first of these being transportation infrastructure, and the second being urban regeneration. Sustainable development and its relationship to the above topics will also be studied in this research. Cities currently account for half the world's population. By 2030, cities will be inhabited by 60 per cent of the world's population (UNSDG, 2016). It is vital for cities to implement new ways to transport their populations between work, home, shopping, school, and leisure as urban populations grow. It is also vital that cities are planned in a way that take advantage of built-up urban areas with existing services and infrastructure. A focus on medium density zones of municipalities, boroughs, and inner suburbs will allow analysis on the effectiveness of LRT in areas where higher order local transportation may not be warranted by the population densities found there. Studying the impacts of LRT on transportation infrastructure is needed to inform decision makers when determining what order of transportation, and what extent of network is needed to meet their municipality or region's mobility needs.

Regeneration of urban brownfields is also important for several reasons. Brownfields are lands and structures that are known or perceived to be contaminated and thus are left to be largely unused or underused (Greenberg et. al., 2001). As the nature of work in medium sized municipalities, boroughs and inner suburbs change from manufacturing to technology and service industries, a landscape of abandoned and contaminated properties remain (Rizzo et. al, 
2015). By regenerating and decontaminating brownfields, we can reduce community health risks while creating opportunities for redevelopment that are beneficial and needed by the community (Greenberg et. al., 2001). This kind of regeneration also allows for cities to maintain more compact settlements and lessens the need for development on pristine greenfield sites, leaving those sites for agriculture, ecological diversity, and recreation. Studying the impacts of LRT through case studies can show how cities can grow to be more sustainable in their land use designations. Policies and strategies encouraging density around transit stops will be studied. Examining how brownfield sites are affected by the development of LRT is important to the issues of sprawl, commute times, and sustainable development. Pursuing this research helps to advance the planning profession and practice because transportation infrastructure, urban regeneration, as well as sustainable development, are problems that will be ubiquitous in the $21^{\text {st }}$ century.

Three case studies will be used to examine the contexts, policies, designs, and impacts, of the implementation of light rail transit (LRT). By asking the question of how are the case studies similar, different, and distinct, the lessons learned will inform future decisions for this category of project. The Region of Waterloo, Los Angeles, and London (UK), are all at various stages of contemporary implementation of light rail transit, and will serve as the subjects of the case studies. The case studies will focus on the intersection of transportation and land-use, with an emphasis on light rail's effects on the regeneration of urban brownfield sites. An analysis on the effects of these projects will be viewed through the lenses of stakeholders, local economies, social implications, and environmental impacts. The research for this topic will be quantitative and qualitative. Quantitative data will be in the form of development data and applications, while qualitative data will be in the form of both primary and secondary research, as well as through 
the use of subject interviews. Each case study is a focus on subpopulations of a larger urban area. By focusing on the borough of Croydon (London, UK), the inner suburbs in the Exposition Corridor (Los Angeles), and the City of Waterloo (Region of Waterloo), this paper hopes to inform future work for urban areas with subpopulations of 100,000-500,000, in order to help fill gaps in transportation and brownfield regeneration literature.

\subsection{Literature Review}

After reviewing a larger pool of literature, the following journal articles and books were chosen to take a closer look at the subtopics of my research; brownfields in general, transportation infrastructure, urban redevelopment, as well as sustainable development. A brief review of each will be presented, followed by findings as they relate to this research, including a review of gaps in the literature.

\subsubsection{Brownfields - Brownfield Redevelopment}

The article Brownfield Redevelopment as a Smart Growth Option in the United States, Greenberg, Lowrie, Mayer, Miller, and Solitare (2001) provides a concise and informative primer on brownfield redevelopment, as well as comparing the advantages and disadvantages with other 'smart growth options'. Smart growth is defined as clustering people and their activities in central areas or along corridors which are already developed, thus avoiding greenfield development. Brownfield redevelopment as a smart growth option is when "policy centered on brownfield redevelopment directs legislation, dollars, and government's moral powers toward attracting developers and individual investors, non-profit organizations, and community groups to neighbourhoods with underutilized or abandoned properties rather than to 
pristine greenfield" (pg. 130). The authors establish strong policy options that make brownfields more attractive to development such as making it financially challenging for businesses or land owners to keep those sites underused or vacant, and using public funds to invest in infrastructure and services in the neighbourhoods that contain brownfield sites. The authors also provide five smart growth options which include: enticing development through the construction of light rail line and other transit options, protecting greenfields from development, and rewarding developers for building in central areas. The authors acknowledge that there are gaps in information around brownfield redevelopment, though this kind of redevelopment presents itself as the smartest and most effective smart growth policy. Six specific policy recommendations are suggest by the authors in order to draw development attention to neighbourhoods with brownfield sites. The policy recommendations are as follows:

1) making the redevelopment of neighborhoods with brownfields an unambiguous bipartisan priority;

2) locating or expanding government facilities in these places;

3) providing incentives to private investors who locate in desired neighborhoods, including funds to remediate sites and demolish buildings, tax reductions and liability protection;

4) making it financially painful for businesses and speculators to retain brownfield properties in an unused or underutilized mothballed state;

5) providing funds to upgrade and/or add infrastructure, police, fire, sanitation, social and public health and other key services to improve the quality of neighborhoods with brownfields; and 
6) reaching out to individuals who are likely to be attracted to these locations with promotional messages, maps of sites and other information that touts the advantages of these locations, including listing government- supported incentives.

\subsubsection{Transportation Infrastructure - Light Rail Transit}

In their article Generating Opportunities for City Sustainability through Investments in Light Rail Systems: Introduction to the Special Section on Light Rail and Urban Sustainability, Ferbrache and Knowles (2016) introduce the many benefits of light rail transit. They point out that effective routes and connections of an LRT system can improve urban flows, create better accessibility and increase the quality of urban centres. LRT is viewed positively in the way that it is much more affordable and requires less engineering than underground heavy rail systems, and that unlike most busways, LRT enjoys dedicated rights of way in most scenarios. LRT is also advantageous because it carries more passengers and travels at higher speeds than traditional busways. LRT also has a proven ability to attract motorists to switch modes and by doing so, relieves traffic congestion. The authors frame sustainable mobility as being centred around public transit and active transportation, and point to how not only is active transportation needed to get to and from LRT, but that walking and cycling paths are often physical features found in and around LRT stops.

In the article entitled Framing light rail projects - Case studies from Bergen, Angers and Bern, Olsen (2014) examines what rationalities and arguments are present when local decisionmakers choose to implement LRT. Olsen also makes reference to urban centres and LRT. He points out that LRT is often used to upgrade public transportation systems in order to increase mobility and reduce congestion in urban centres. Olsen also points to the lower cost of LRT 
when compared to heavy rail options. Olsen concludes that LRTs often are used to form the backbone of transportation networks. This in turn leads to intensified and sustainable urban development, and increase options for transportation infrastructure.

\subsubsection{Urban Redevelopment - Brownfields and Transportation}

The United States Environmental Protection Agency defines a brownfield as "a property, the expansion, redevelopment, or reuse of which may be complicated by the presence or potential presence of a hazardous substance, pollutant, or contaminant" (EPA, 2018). Amekudzi and Fomunung (2004), performed an analysis of ten case studies in the United States. The paper is entitled Integrating Brownfields Redevelopment with Transportation Planning. The analysis focuses on the various ways secondary U.S. cities regenerated brownfields with transportation policy. The paper highlighted how brownfield sites are being inventoried by local and state government and how a growing number of brownfield redevelopments have transportation elements that are vital to their success. Transportation in this context, largely had to do with expanding or upgrading existing road networks, creating busways, or connecting these developments to heavy rail. Only one of the case studies had a LRT component to its transportation plan; the Salt Lake City Gateway District. The project consisted of 650 acres of former industrial and rail lands on the western edge of downtown. The redevelopment was centred on a multi-modal approach to redevelopment with a north-south LRT line built concurrently with development, and plans for an east-west line being finalized while development was occurring. The authors found that this project was an example of a larger brownfield area where the simultaneous development of transportation was needed for any regeneration to occur. The benefits of this regeneration were multiple, and provided job creation, 
tax base enhancement, environmental remediation, and infrastructural renewal. The authors concluded that transportation improvement projects can be used proactively to incentivise brownfield redevelopment, and that this is desirable due to the economic, social, and environmental benefits that come with brownfield regeneration. This process can be further accelerated by adopting formal policies linking transportation and brownfields on a local or state level. The authors state five specific policies which can use transportation planning to driving the brownfield corridor and area redevelopment. The policy recommendations are:

1) Locating transportation projects (of local scale) expressly on brownfields to qualify brownfield redevelopments for transportation funds (where funding is a constraint for jumpstarting redevelopment in a brownfields area or corridor);

2) Locating transportation projects (of corridor scale) in brownfield corridors or areas to spur the redevelopment of brownfields in blighted corridors, e.g., renewing obsolete to improve the appeal of brownfield corridors to potential developers;

3) Including transportation projects in the metropolitan and state transportation improvement programs (TIPS);

4) Identifying brownfield corridors that can be strategically converted into bicycle or walking trails to enhance the economy and environment of the surrounding areas; and

5) Developing brownfield/transportation organizational infrastructure (formal relationships between brownfield redevelopment agencies and transportation planning agencies) to coordinate brownfields and transportation plans. 


\subsubsection{Sustainable Development - Transit and Land Use Integration}

Susuki, Cervero, and Iuchi (2013), performed an in depth analysis of transit and land use integration in their work Transforming Cities with Transit : Transit and Land-Use Integration for Sustainable Urban Development. The overarching theme of this book is that by building well-integrated transit and land development, we can create spaces that require less travel by automobiles, are encouraging of active transportation (walking biking), are attractive for working and living, and reduce local pollution and greenhouse gases. In other words, these are the goals of transit-oriented development (TOD). The book uses case studies from around the world to demonstrate transit-oriented development in both 'global cities' and in the 'cities of developing world'. The authors identified several points of insight in how the case study cities have moved toward transit and land use integration. These are grouped into "strategic vision and enabling institutional and regulatory framework", "city-level planning approach", "promoting and implementing transit-oriented development", and "financing scheme". This provides a firm and proven blueprint to sustainable development through TOD. Though this book focuses on bus rapid transit as its primary transportation intervention, the overall lessons in TOD are applicable to this topic.

\subsubsection{Synthesis of Literature}

From the above readings as well as the broader pool of literature, several findings have been determined. These findings will help to inform the analysis and recommendations of this paper. The first key finding is that brownfield redevelopment is a form of smart growth with the possibility of strong policies to encourage urban regeneration (Greenberg et. al 2001). Smart growth is where policies are used to encourage activity and development in central areas or along 
developed corridors, and while there are gaps in the research on brownfield redevelopment, it appears to be the most effective form of smart growth (Greenberg et. al. 2001).

The second key finding is that effective LRT routes and connection create better urban flows, accessibility, and quality of urban centres (Ruffilli, 2010; Olsen, 2014; Ferbrache \& Knowles, 2016). Because LRT is more affordable and requires less engineering than heavy rail (Olsen, 2014; Ferbrache \& Knowles, 2016), and due to the fact that LRT carries more passengers and can travel at higher speeds than buses (Ruffilli, 2010; Ferbrache \& Knowles, 2016), this form of infrastructure investment becomes attractive to in urban areas that need a higher order of transportation but cannot justify heavy rail. Additionally, LRT encourages , but does not directly promote, active transportation (Ferbrache \& Knowles, 2016; Hong et. al., 2016).

The synthesis of these two key findings is that while Brownfield redevelopment can create economic, social, and environmental benefits (Amekudzi \& Fomunung, 2004, Wang et. al. 2011), simultaneous development of transportation and brownfield development are crucial to it's success (Johnson et. al., 2002; Amekudzi \& Fomunung, 2004; Tremblay-Racicot \& Mercier, 2014). This is because policies linking brownfields and transportation development accelerate regeneration of brownfield sites (Amekudzi \& Fomunung, 2004). Furthermore, Well-integrated transit and land development can lead to less driving, more active transportation, attractive live/work districts, and can reduce local pollution (Suzuki et. al, 2013; Tremblay-Racicot \& Mercier, 2014).

While frameworks have been developed to encourage transit oriented development at the 'global city' and 'developing world city' scales (Suzuki et. al. ,2013), there is not abundant research in this area. The aim of this research is to be able to validate the findings in existing 
literature, and to analyses the success of the synthesis between LRT and brownfield redevelopment.

\subsubsection{Gaps in Research}

The findings above show that there are positive correlations between transportation infrastructure and urban regeneration. But there are gaps in terms of the objectives of this paper. While much attention is paid to the world's 'global cities' and the 'developing world', there is a gap in literature and research for small-medium sized municipalities, inner suburbs, and urban boroughs in the 'developed world'. There is also a gap in the literature around LRT specific projects and their intersection with brownfield regeneration.

\subsection{Background}

The following section will provide background on policy and practice that will become relevant in understanding this paper's case studies. These will include a background on the financing of large infrastructure projects, along with key policies that shape infrastructure and transportation projects.

\subsubsection{Financing LRT: Traditional Government Financing}

In Canada, there are several sources for financing infrastructure. Two of these are best used for financing public transit; user fees, and transfers (Bird \& Slack, 2017). User fees are an important tool when financing services considered to be a private good. This is because user pay directly for the service and the revenues generated by it are reinvested into that service. Transit 
fares are a form of user fee. Transit fares account for $70-80 \%$ of operating costs for transit in the Greater Toronto Hamilton Area (Bird \& Slack, 2017).

Transfers from higher levels of government are also an important way to pay for infrastructure. Transfers are appropriate where the benefits of various forms of infrastructure spill into multiple jurisdictions. Transfers are also necessary for municipal governments due to their lack of revenue generating tools. A major source of infrastructure funding in Canada is The Federal Gas Tax Fund (GTF). The GTF is a permanent and reliable source of funding provided by the federal government and transferred to the provinces twice a year. These funds are then distributed to individual municipalities, based on their infrastructure needs. Each year, the GTF delivers over $\$ 2$ billion in funding to approximately 4000 projects (Infrastructure Canada, 2018). In Canada, municipalities own nearly two thirds of all public infrastructure (FCM, 2018). This necessitates that on many larger public transit investments, all three levels of government contribute to the funding of these projects. An example of this is the Toronto-York Spadina Subway Extension (TTC, 2017), or the Ottawa Confederation Line LRT project (City of Ottawa, 2018).

\subsubsection{Financing LRT: Public-Private Partnerships}

Public-private Partnerships (PPPs or P3s) are a form of contract where the private sector is involved in infrastructure projects. This form of partnership became popular with governments in the 1980s, and now plays an important role in many large scale infrastructure projects around the world (Siemiatycki, 2009). PPPs are defined by The Canadian Council for Public-Private Partnerships as (CCPPP, 2005-16): 
A cooperative venture between the public and private sectors, built on the expertise of each partner, that best meets clearly defined public needs through the appropriate allocation of resources, risks and rewards.

The benefit of PPPs is that by introducing private financing, competition, and market forces into the development of public infrastructure, projects can be completed faster and at less expense than if the public were to undertake the project alone (Siemiatycki, 2009).

PPPs are delivered with varying degrees of public/private responsibility. These can be categorized into four models of PPPs, arranged from greater public to private responsibility (Siemiatycki, 2009):

- Design-Bid-Build (DBB);

- $\quad$ Design-Build (DB);

- Design-Build-Finance-Operate (DBFO); and

- Build-Own-Operate (BOO).

In DBB, almost all aspects of the project are in public control, with the private sector working as consultant and contractor. In BOO, the private sector controls all aspects of the project with only user fee rates subject to government regulation. DBFOs have become the favored model for large transportation infrastructure projects in the United States (Federal Highway Administration, 2017). In Toronto, the $\$ 9.1$ billion Eglinton Crosstown LRT, is a variation of the DBFO. In this case the public sector will operate the line upon completion, while the private sector will design, build, finance, and maintain the project (Infrastructure Ontario, N.D.) 


\subsubsection{Financing LRT: Land Value Capture}

Land value capture is a method to capture the increased value of land due to one of two forms of public intervention. The intervention takes the form of either public investment, or change in regulation (Bird \& Slack, 2017). One way land value is captured based on public investment is to impose a special assessment tax. This is when a specific levy or fee is attached to the existing property tax rate on specific properties the directly border or benefit from a public investment. Examples of this are when roads or water mains are constructed, the properties who directly benefit may be asked to pay a fee spread out over several years to recoup the cost of the investment. This draws a direct link between those who benefit and those who pay for infrastructure (Bird \& Slack 2017).

The other form of land value capture based on public investment is tax increment financing (TIF). This is where the property tax rate before an investment remains constant for a set amount of time (fifteen to thirty years), and any increased property tax due increased assessed value are then directed into a special fund dedicated to repaying the public investment (Bird \& Slack, 2017). While TIFs are widely used in the United States they are not as common in Canada. The work of Haider and Donaldson (2016) show that while TIFs are a good tool for many infrastructure projects, the vast amount of investment required in public transit projects cannot be captured by TIFs alone. For example, a simulation was run to see if TIFs could have paid for the City of Toronto's Sheppard Subway line. In their simulation no more than 10-50\% of the full capital cost was covered in various scenarios. Had a TIF been applied to all 15,000 residences in the corridor, $50 \%$ of the capital cost would have been covered, but they warned that freezing property taxes for a thirty-year period on those residences could lead to service 
shortfalls as any increase in property tax would have to go to the TIF (Haider and Donaldson, 2016).

Finally, land value capture can be executed in the form of changes to regulation. Governments can enact land use regulation that allows for exchanging density bonuses in order to secure benefits from developers (Bird \& Slack, 2017). This takes place when a developer would like to exceed existing zoning by-law restrictions. In Ontario, Sec. 37 of the Planning Act allows for local municipalities to "...authorize increases in the height and density of development otherwise permitted by the by-law that will be permitted in return for the provision of such facilities, services or matters as are set out in the by-law" (Planning Act, 1990).

These forms of land value capture are equitable because those who are to benefit from the public investment are also required to pay for a part of that benefit. Though it is also important to note that land value capture generally does not generate enough revenue to cover the cost of large infrastructure projects like public transit. Land value capture should be a compliment to other more reliable sources of revenue like government financing (Chapman, 2017).

\subsubsection{Official Plans \& Growth Plans}

Official plans and growth plans are tools that local and regional decision makers use to manage growth and development in their jurisdictions. Official plans and growth plans are generally put forward by a municipality’s planning department or Mayor, and passed by a

municipality's council (Mayor of London, 2019; City of Toronto 1998-2019). These plans are used as a spatial development strategy, and work as an integrated economic, environmental, transport and social framework for a municipality to work towards over a 20-30 year period (Mayor of London, 2019). 
Growth plan policies can also exist on scales larger than local and regional. For example, the Province of Ontario's Place's to Grow Act (2005), is a tool to achieve growth policy and implementation for the entire province. The Act works as a guide for (Ontario, 2008-2019):

- designation of any geographic region of the province as a growth area with a specific focus;

- development of a growth plan in consultation with local officials, stakeholders, public groups, and members of the public and Indigenous communities for a particular region; and

- decisions about growth to be made in ways that increases and promotes greater housing and transportation options, investments in regional public service facilities in downtown areas, and maximizes infrastructure investments in communities, while balancing regional needs for farmland and natural areas.

As will be seen in the case study analysis to follow, the planning justifications for all three case studies refer back to their local or regional official plans and growth plans. It is in these plans that planners and decision makers create the policies that lead to the symbiotic relationship between transportation and development. It is here that transit oriented development, smart growth and the simultaneous development of transportation and land use can be prioritised, and institutionalised. 


\subsection{Methods}

\subsubsection{Research Goals}

The aims of the below methods are to best answer the research questions that have been posed. A quantitative analysis aims to provide hard numbers regarding these projects and works to inform the broader primary research question (What are the Impacts of Light Rail Transit on the Regeneration of Urban Brownfield Areas?). A qualitative analysis of policy and geospatial data will help to answer the first of the secondary questions (How Does Transportation Infrastructure, Urban Redevelopment, and Sustainable Development Impact the Decision to Implement Light Rail Transit and Regenerate Urban Brownfield Areas?), while the subject interviews intend to answer the second secondary question (How Do Stakeholders, Local Economies, Social Fabrics, and Environments Impact These Decisions and How are They Affected by Them?).

\subsubsection{Quantitative Analysis:}

For all three case studies, a broad quantitative analysis was attempted. Census data over temporal scales (before and after implementation of light rail), a demographic study of population, land values, as well as industry profiles were proposed to examine the effects. An analysis of development applications was employed to identify where brownfield redevelopment has occurred.

\subsubsection{Qualitative Analysis:}

The examination of policies regarding implementation of light rail transit and surrounding redevelopment will set the context of how these projects came to fruition. This will 
include State/Provincial directives/initiatives, official plans, secondary plans, and site specific plans. Geospatial analysis of each case study's physical location, along with any available zoning/land use, and transportation routing documents were explored. Semi-structured subject interviews were identified as a desirable form of analysis. Interviews were chosen as a methodology in order to attempt to gain firsthand knowledge on the subject. The subjects being 'experts', which include city planners, local politicians, and/or engineers from the LRT project. These experts would have knowledge and insight into these project that might not be present in planning, procurement, or other detailed documents. It is through interviews that questions such as 'what if' or 'how come' can be more accurately addressed. These interviews were designed to be semi-structured to ensure that a defined set of question will be answered, but to also leave room to explore other themes or responses further.

\subsection{Rationale for Case Studies}

Case studies were chosen as a methodology for this paper due to their extensive use in urban planning papers, journals, and texts. As seen in this paper's literature review, Olsen (2014), Susuki, Cervero, and Iuchi (2013), and Amekudzi and Fomunung (2004), all use case studies to compare, contrast, and synthesise their research. The use of case studies allows for analysis to transcend the physical and geographic confines of one urban area, leading to potential crosspollination of best practices and lessons learned.

The three case studies were chosen for several reasons. The primary reason for their selection is that they all have modern (year 2000 and newer) LRT line(s). These lines all feed into regional transportation networks, meaning they are not isolated in their use. All three have chosen to alter their current urban form to accommodate LRT, as opposed to building new areas 
served by new transit. Second, they are all in areas that are either situated inside an urbanised area or are rapidly urbanising. Third, they are all located within the Anglosphere, meaning that they all have common roots in culture and history, making the case studies more relatable. Fourth, they are all within a single jurisdictional framework, meaning they have a singular uppertier governance structure, as opposed to being intertwined in multiple jurisdictions, i.e. New York City or Washington D.C. Finally, these cases were all chosen because of the potential they have on urban regeneration. These cases are all situated within older urban areas with direct connection to underused and contaminated lands.

\subsubsection{Croydon, London, UK}

Croydon is a borough and inner suburb in the south of London. As of 2011, it's population was 363,000 and it is expecting growth of 30,000 people by 2031 (London Borough of Croydon, 2018). Croydon has a long history of industry and urban growth. It became a major railway town in the early 1800s and by 1914 was home to London's original airport. This led to major population growth and industrialisation in the borough (London Borough of Croydon, 2018). Croydon's LRT system is referred to as Tramlink, and has been in operation since May 2000. The system is served by 39 stops on $28 \mathrm{~km}$ of track (TfL, N.D.).

\subsubsection{Exposition Corridor, Los Angeles}

The Exposition Corridor is the area on either side of the Metro Exposition Line LRT located in Los Angeles, California. Specifically, the Exposition Corridor is a segment of the larger LRT line and is comprised of five stations (Bundy, Sepulveda, Westwood, Palms, and Culver City). The corridor runs through six neighbourhoods, which cover approximately 14.87 
square miles and have a combined population of 163,937 (LA Times, 2009). These neighbourhoods are part of the larger Westside of Los Angeles, which has a population of 529,427 and covers 101.28 square miles (LA Times, 2009). The Metro Exposition Line opened in 2012, running from Downtown Los Angeles in the east, to the initial terminus of Culver City Station in the west. The line was expanded westward to Santa Monica in 2016 with the four additional stops in the Expo Corridor being built, along with another four stops west of the corridor. The overall Expo Line is served by 19 stops on $24.5 \mathrm{~km}$ of track (LA Metro, 2017-18)

\subsubsection{Waterloo, Ontario}

The City of Waterloo is roughly 100km southwest of Toronto. In 2016 it had a population of 104,986 and the Region of Waterloo had a 2016 population of 535,154 (StatCan, 2018). Set to open in 2019, ION Rapid Transit will serve to connect the neighbouring cities of Waterloo and Kitchener, and eventually the city of Cambridge to the south. The line will be served by 19 stops on $19 \mathrm{~km}$ of track (Region of Waterloo, 2017)

\subsection{Methodological Limitations}

While this paper set out research goals using quantitative and qualitative methods, there were several limitations in the ability to fully investigate the research questions set out in the paper. These limitations had mostly to do with geography, institutional process, as well as time and money.

Access to information at a proper geography was one of the largest limitations to this paper. Each case study is located in different jurisdictions, where institutional processes are quite 
unalike. These different locations were selected in order to get a wide range of projects and to find common ground among them. Each case study's jurisdiction have different ways of providing online information around building permits, planning documents and approvals, and official plans. What was found is that for of the information needed for the quantitative analysis, most of the information needed was not available online, and if it was, there was no standardised format in which to make proper empirical comparison.

As mentioned above in the qualitative analysis section of methodology, it was desired for this paper to conduct interviews with professionals in order to obtain a better understanding of the processes behind LRT implementation. In the end these interviews were not conducted, but a waiver for Research Ethics Board approval was submitted and granted prior to any attempt to conduct interviews with professionals. The following were the questions that were prepared:

\section{Project Background}

- What prompted the project?

- How was the project justified?

- What was your involvement with the project?

Planning:

- Did land use availability affect the route?

- How does LRT unlock land use?

Funding

- When was funding applied for?

- What was the funding model?

- When was funding approved?

Professional Opinion

- What would you do if you had to do it again?

- What did you not expect?

- Did the funding model work as anticipated?

- Were brownfield and greyfield sites redeveloped/revitalized as a result of this project?

- Is LRT development an appropriate tool for unlocking brownfield and greyfield sites?

- Would these brownfield sites in your jurisdiction have been revitalized without the infrastructure investment? 
It was not the intent for all of the above questions to be answered in detail, but more to become the framework around a professionally informed discussion on the subject matter. What became the major limitation for the interviews was also geographical. Because this research was to take place over the phone/internet, and with no referrals or introductions, it became impossible to located anyone qualified to participate in the interviews. A more detailed description of this process will be conveyed in s. 4.1.2 Limitations of Case Studies.

A Master's Research Paper (MRP), such as this, has a much shorter timeframe than a thesis paper. Had there been more time, relationships might have been better discovered in order to unearth potential interview candidates. Also had funding for travel been included, "boots-onthe-ground" research could have taken place, such as going to planning desks and directly requesting information not available online.

\subsection{Realized Method of Analysis for Case Studies}

The method for analysing the case studies was to standardize the approach to each, in order to be able to perform meaningful analysis. The goal of standardizing these methods is to enable decision makers in various jurisdictions to be able to read the case studies in a way that can help inform their own decisions about transportation infrastructure investment and land use policy. In other words, positive outcomes could be used as best practice guides.

The first step for each case study was to first identify how each of these major infrastructure projects were financed. This allows for thoughtful analysis on whether these methods of financing are viable and/or warranted in other jurisdictions. 
The second step was to identify the relevant planning policy that governs land use and transportation planning in and around the three case study LRT lines, along with a brief history of the origins of these lines.

The third step was to then identify properties that have undergone redevelopment adjacent to the respective LRT lines. Once these properties were identified, analysis of the relevant planning policies, as well as planning justifications (where available) were used to analyse if these brownfield developments were a direct result of the investment in LRT infrastructure.

\subsection{Expected Outcome/Contribution to knowledge and Policy}

Based on the literature review, a positive correlation between Light Rail Transit and Urban Brownfield Regeneration is expected. This expectation is based on current knowledge, though as the gaps in literature show, the scale of city studied most often does not align with this project. Current literature on this topic is not exhaustive, thus a positive correlation is anticipated but far from guaranteed. Again, as noted in the literature gaps, little research is available for the scale of inner suburb/borough/medium sized city. The advancement of this work will contribute to knowledge and policy for future projects on this scale. Should all three case studies show a positive correlation, findings should be synthesized in future policy and decision making processes. Should negative relationships be found, this can help to inform where further analysis is needed or where alternative decisions can be made. 


\subsection{Problem Investigation}

The following section used case studies in order to attempt answering this paper's research questions. This section describes traditional funding models for financing large infrastructure projects, such as LRT, followed by how each of the case studies were themselves financed. To conclude the problem investigation section of this paper, an in-depth policy, planning, and development analysis was performed for each of the three case studies. The analysis focuses on planning policy that is in place, followed by an examination of development effected by them.

\subsection{Financing LRT: Case Studies}

\subsubsection{Croydon Tramlink}

The London Borough of Croydon's Tramlink is a 39 stop, $28 \mathrm{~km}$ light rail transit line that began operation in 2000, and connects central Croydon to the rest of the borough (TfL, N.D.). This line was financed through a Public-Private Partnership, which is referred to as a Private Finance Initiative (PFI) in the UK. The UK has pioneered the trend of financing large infrastructure projects through PFIs, and as of 2006, upwards of $13 \%$ of all investment in public infrastructure in the UK were PFIs (Deloitte, 2006). The Croydon Tramlink was one of the first transportation Design-Build-Finance-Operate (DBFO) PFIs in the UK, and the PFI was touted as being the only way to finance the project (Siemiatycki, 2009). Tramlink was projected to cost $£ 200$ million, with $£ 125$ coming from the central government of Britain. The remainder of the funds were to come from the winning bid consortium, Tramtrack Croydon, who were awarded a 99-year DBFO contract. Tramtrack would be responsible for any risk associated with the project, including any cost overruns, and their costs were to be recovered solely through fares on the new 
line. While the project came in at budget, ridership projections did not, and in the first years of operation, Tramtrack amassed debts of up to $£ 100$ million (Siemiatycki, 2009). On June 27, 2008, the regional transit agency for London, Transport for London (TfL), purchased the Croydon Tramlink from Tramtrack Croydon, buying out the remaining 88-year lease for $£ 98$ million (Transport for London 2008/09). The takeover by TfL allowed for an immediate increase in service and put an end to public subsidies (due to fare and ticketing policy changes by TfL) that were being paid annually to Tramlink. The subsidy in 2007 alone was $£ 4$ million, with that amount set to increase substantially over the remaining 88-year lease (Transport for London, 2008).

\subsubsection{Exposition Line}

The City of Los Angeles' Metro Exposition Line is a 19 stop, $24.5 \mathrm{~km}$ light rail transit line that began operation in 2012 and runs from Downtown Los Angeles to Santa Monica. The first phase ran about half the length to Culver City, and phase two opened in 2016 running west to Santa Monica (Metro, 2017-18). This rapid transit line was financed entirely by traditional government financing. The County of Los Angeles has several tools to finance infrastructure. It is important to note that the Los Angeles County Metropolitan Transportation Authority is responsible for all forms of transportation in Los Angeles County, including highway financing and maintenance (Metro, 2017-18). This gives the agency a wholistic approach to all transportation infrastructure projects in the County. The primary source of Countywide transportation funding are from four local sales taxes, each being a $1 \frac{1}{2} \%$ sales tax. These are known as Propositions A (1980) and C (1990), as well as Measures R (2008) and M (2016) 
(Metro, 2017-18). Metro also receives revenue from portions of the State gasoline tax and the Federal fuel excise tax (Metro, 2017).

At the time of the Exposition line's construction, only Propositions A and C, and Measure R were active. The majority of the funding comes from Measure $\mathrm{R}$ which is dedicated to fund traffic relief and rail expansion. Measure R became effective in July, 2009, and after its first full year generated $\$ 551,480$. By 2017, Measure R generated $\$ 764,968$ in annual, sustainable transit infrastructure funds (Metro, 2017-18).

\subsubsection{Ion Rapid Transit}

The region of Waterloo's ION Rapid Transit is a 19 stop, $19 \mathrm{~km}$ light rail transit line set to open in 2019. The line will link the urban centers of the cities of Kitchener and Waterloo (Region of Waterloo, 2017). This project is being coordinated by Infrastructure Ontario and jointly developed by the Region of Waterloo, and the winning bid consortium, Grandlinq GP. Grandlinq is responsible for the design, build, financing, operation, and maintenance (DBFOM) of the new light rail line (Region of Waterloo, 2013). The operating contracts is for 10 years, with the option to extend, and maintenance is a 30-year contract. Grandlinq will be responsible for all cost overruns, delays, and performance issues over the length of the contract (Grandlinq Contractors, 2014). The project is to remain in public ownership, and will be fully integrated into the region's existing public transit system, Grand River Transit. Funding for the line is being delivered by all three levels of government (Infrastructure Ontario, N.D.). The cost is being split almost equally by the governments of Ontario and Canada, \$300 million and \$265 million respectively, and the Region of Waterloo with a contribution of \$253 million (region of Waterloo, N.D.). 


\subsection{Policy, Planning, and Development Analysis: Case Studies}
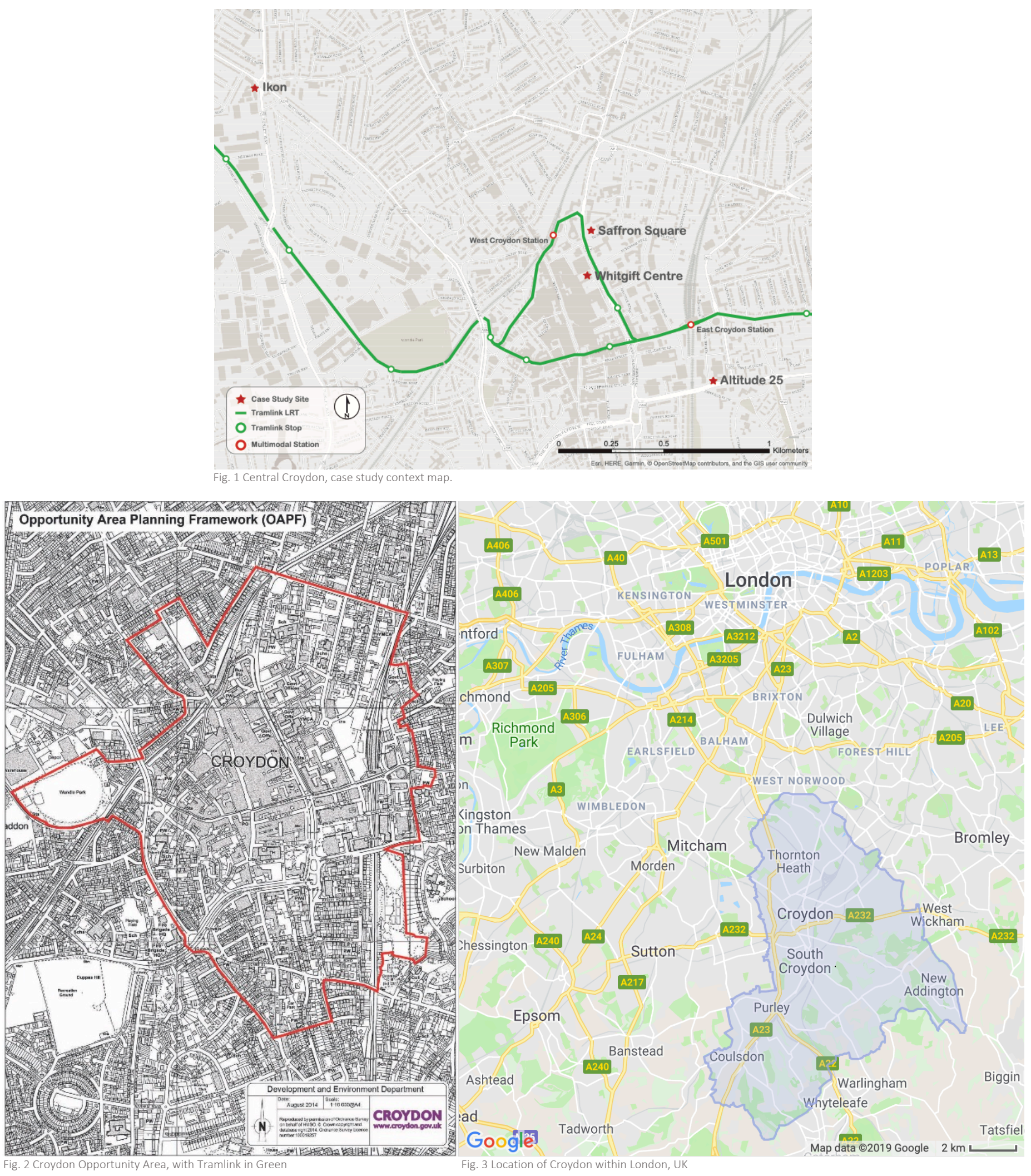


\subsubsection{Croydon Tramlink}

The Borough of Croydon's central area is designated as an 'Opportunity Area' by the Mayor's Plan for London (Fig. 2). Opportunity Areas are a response to the reality that the City of London has very limited space left to accommodate any large scale development. The Opportunity Areas are described as London's major source of brownfield land, and that they have significant capacity for development and improved public transportation access (Greater London Authority, 2019). The Croydon Opportunity Area Planning Framework (COAPF), was adopted as a supplementary planning document to the Croydon Local Plan by Croydon council in 2013, and was jointly prepared by the Greater London Authority and the London Borough

Council in partnership with Transport for London (Croydon Council, 2019). Being that this plan was developed in partnership with Transport for London demonstrates the focus on transit oriented (re)development. The Croydon Local Plan 2018, identifies 55 specific sites within the Croydon Opportunity Area that are proposed for development and redevelopment, the majority of which are on existing brownfield sites (London Borough of Croydon, 2018). To understand further the relationship between transportation and development in Croydon, the following will focus on the role of Tramlink LRT in central Croydon, as well as four recent redevelopments of brownfield sites adjacent to Tramlink stations.

In operation since 1999, Tramlink runs from suburban areas to the east and west of Croydon, connecting through the heart of Croydon as it forms a loop around the town centre (Fig.1). There are two major transit interchanges in the Croydon Opportunity Area (COA), West Croydon Station, and East Croydon Station. All Tramlink trams stop at these stations, and these heavy rail stations act as bookends to the town centre. Both stations are serviced by National Rail, while West Croydon Station is also serviced by Transport for London (TfL) Overground 
service. Tramlink works as a connector for these interchanges as well as moving people out to the broader Croydon area. The Croydon Local Plan 2018, identifies not only branch extensions, but also the desire to create a new loop in central Croydon (Borough of Croydon, 2018). This would address congestion and capacity issues. The 2018 plan places a great deal of emphasis on tram infrastructure improvements and extensions, in order to accommodate current and future growth of use, with the hope that extensions could create a mode shift on corridors leading into and out of Central Croydon (Borough of Croydon, 2018). The 2018 Plan ensures that no development will be supported by council that might prejudice the implementation of "infrastructure extensions or other operational improvements to increase capacity of the Tramlink network" (Borough of Croydon, 2018).

Altitude 25 is a twenty-five storey residential development located within $500 \mathrm{~m}$ of East Croydon Station, on Altyre Road (Fig.1). At the time of its construction, Altitude 25 was the tallest building in Croydon. The planning rationale submitted for this project makes the case that the sustainability of this development was one of its key performance indicators (Vector Design, 2007). The planning documents state that the site is a brownfield with very low ecological value, and that one of its main assets is its proximity to transport links. The project's sustainability report states that the site could not be better placed in terms of access to transportation, such as the tram (Vector Design, 2007). These are confirmed in the decision notice issued by the local planning authority (Croydon Planning and Transportation Department, 2008). This development was ahead of its time in a planning context, as nearby George Street is now designated as a High Street that will be improved (including the relocation of the tram stop) in order to facilitate further regeneration of adjacent brownfield sites (Croydon OAPF, 2013). 
Saffron Square is a large mixed-use development located on Wellesley Road, directly adjacent to West Croydon Station (Fig. 1). The development includes a forty-three storey residential tower, which is the tallest building in Croydon. The development is a former brownfield site that links older residential to the north and east, shopping to the west, and office to the west and south (HTA, 2007). The development fronts onto Wellesley Road, which carries Tramlink. The planning reports for this project are very similar to those of Altitude 25 . The reports stress National, Regional, and local planning policies encouraging sustainable and compact cities, large residential schemes being in areas of high public transport accessibility, growth centres, and Croydon as an Opportunity Area (URS, 2007). As with Altitude 25, the adherence to these policies are confirmed in the decision notice from the Planning and Transportation Department.

Another site that is worthy of examination is a residential/commercial redevelopment known as Ikon. The site is approximately $1.5 \mathrm{~km}$ northwest of the Croydon Opportunity Area, and located on the edge of the larger Purley Way Strategic Industrial Location (Fig.1). The site is less than 500m away from two Tramlink stations. This is a much more recent development as the planning statement was prepared in 2015, and is currently in the final stages of construction. The site is a brownfield, formerly occupied by low quality commercial and light industrial uses (Savills, 2015). In the planning statement, much attention is paid to this being a former brownfield site, and that redevelopment of these sites are favoured. What is lacking in this planning statement is the site's relation to transit. In the planning benefits section, the very first item is "The proposals will redevelop this underused brownfield site", but not one of the 10 points mentions proximity to transit (Savills, 2015). The transport assessment, states that the site 
has a Public Transit Accessibility Level Rating of 2, on a scale of 1-6. This is characteristic of 70\% of Croydon (TTP Consulting, 2015).

The last site to be examined is the upcoming redevelopment of the Whitgift Shopping Centre. Whitgift Centre is located in central Croydon, is nearby to West Croydon Rail Station, and surrounded by the Croydon Tramlink’s central loop (Fig. 1). This $£ 1.4$ billion regeneration of the existing shopping centre and adjacent lands, will transform Croydon's central retail centre with a mixed-use development which also includes new residential units. The development's goal is to transform the shopping centre into a UK top 10 shopping, dining and entertainment destination, while creating 5000 jobs and acting as a catalyst for further regeneration of central Croydon (Croydon Partnership, 2016). The planning statement submitted for this development is quite broad, as this project will truly change the face of central Croydon. Section 6.36 goes so far as to state that "In summary, all tiers of planning policy expressly support the uses proposed on the application Site, demonstrating the acceptability of the principle of the development" (Quad, 2016). Similar to the aforementioned sites, the planning statement makes several mentions of how this is in line with planning policies regarding to the prioritized redevelopment of brownfield sites, and it's integration with public transportation. In the Borough's decision notice, many conditions were applied to this massive redevelopment. The largest concession the developer had to make to the borough was almost $£ 35$ million in public transport measures, which included $£ 24.5$ million for tram network enhancements (Borough of Croydon, 2018). This can be seen as a positive feedback loop, where public investment in transit generated development incentive/pressure, which in turn created an atmosphere where new development generates new investment in transit. 


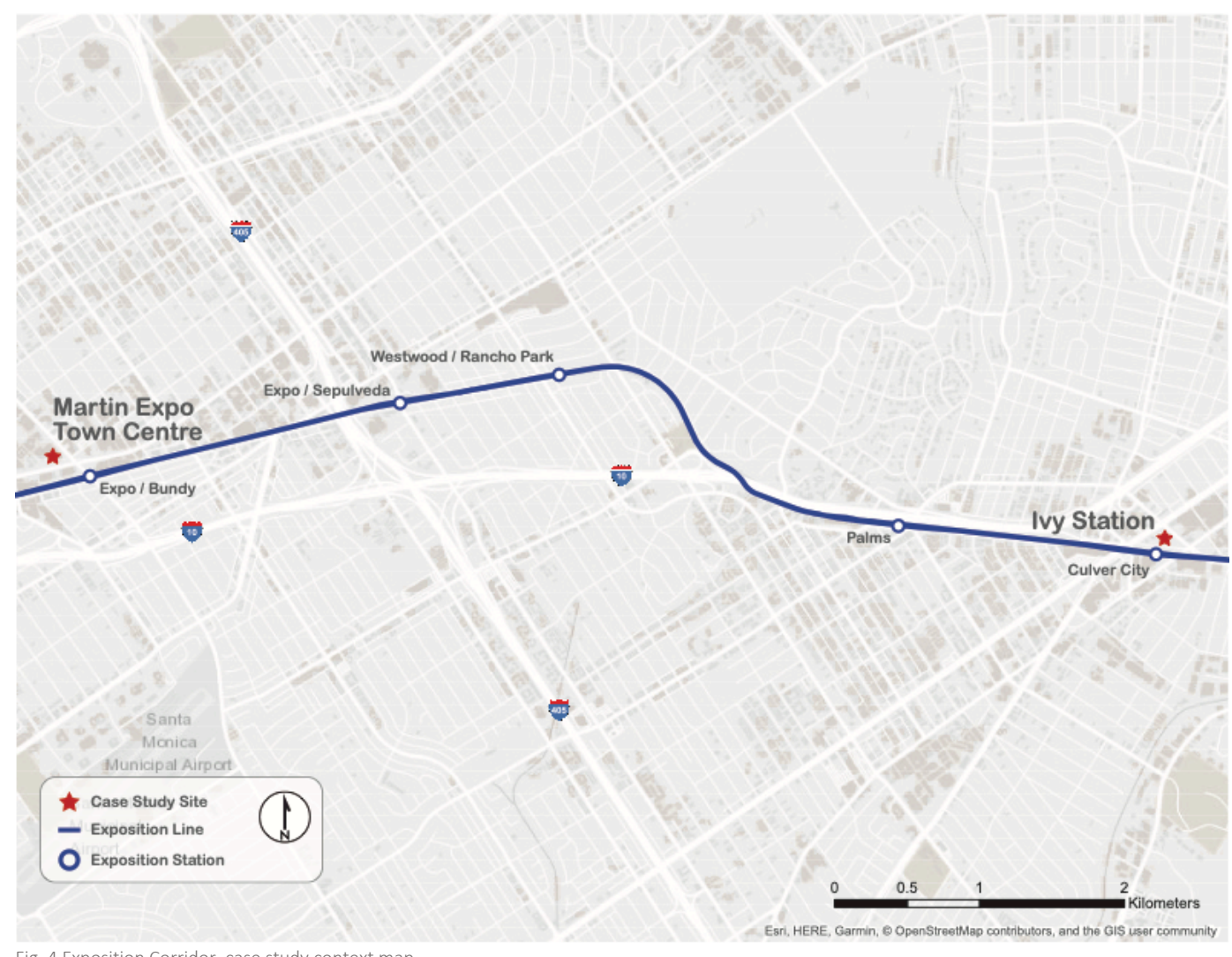

Fig. 4 Exposition Corridor, case study context map.

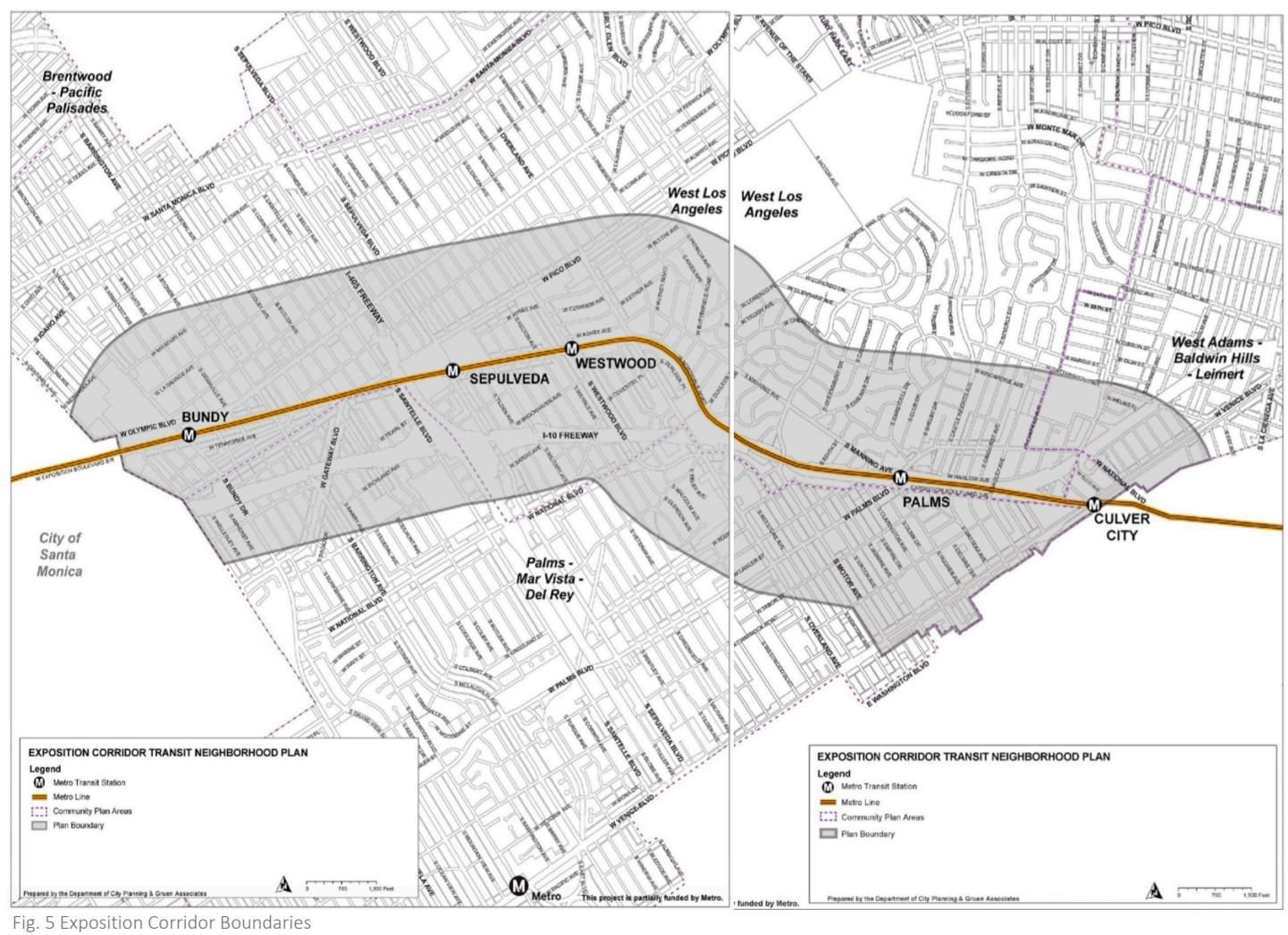




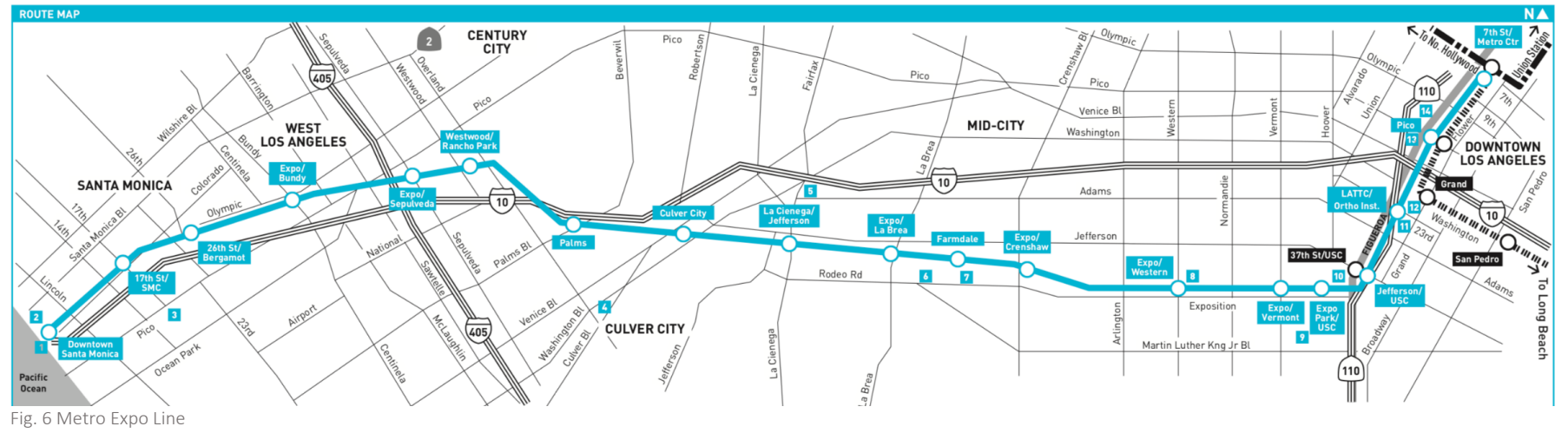

\subsubsection{Exposition Line}

The Exhibition Line, is a light rail transit line which runs from Downtown Los Angeles to Santa Monica (Fig. 6). The Exposition Corridor, is an area which encompasses any property within half a mile of five stations on the Exposition Light Rail Line (Fig. 5). These five stations run westward from and include, Culver City Station in the east, to Bundy Station in the west. In response to the opening of these stations in 2016, the City of Los Angeles undertook planning analysis of the corridor, which resulted in the Exposition Corridor Transit Neighbourhood Plan (LA City Planning Commission, 2017). To understand further the relationship between transportation and development in the Exposition Corridor, this section will focus on the role of the Exposition Corridor Transit Neighbourhood Plan on development in the corridor, as well as two recent redevelopments of brownfield sites adjacent to the Exposition Line.

The City of Los Angeles' Exposition Corridor Transit Neighborhood Plan, is a comprehensive document that addresses all aspects of planning in the Exposition Corridor. The plan was adopted by Los Angeles City Council on July 31 $1^{\text {st }}, 2018$ (City of Los Angeles, 2013). The plan intends to (L.A. City Planning Commission, 2017):

- Direct growth and accommodate new residential, mixed-use, commercial, and industrial development near transit stations; 
- Retain existing industrial land around transit stations for job-generating uses to accommodate future demand for jobs;

- Accommodate emerging industrial sectors and encourage the clustering of creative, clean industry uses, including high tech jobs, within the transit corridor;

- Allow limited residential development in select industrial areas to promote a mix of uses and increase housing capacity in close proximity to transit stations;

- Function as the Transit Oriented Communities Affordable Housing Incentive Program in the New Industry, Hybrid Industrial: Jobs Emphasis, Hybrid Industrial: Residential Emphasis, and Mixed Use: Commercial/Residential zones;

- Implement the policies of the General Plan Framework, which include conserving stable single family neighborhoods and directing growth toward transit corridors;

- Promote transit ridership on the Exposition Light Rail and other transit systems; and

- Ensure new development is pedestrian-oriented, acknowledges the transit stations and remains compatible with surrounding neighborhoods through building design and site planning.

This plan is an interesting approach to brownfield redevelopment, as one of the primary focus of the plan is to preserve industrial use and enhance "New Industry" in and around transit stations. The plan creates three new zoning categories in the corridor for what is known as Hybrid Industrial in the Los Angeles General Plan. These categories are New Industry, Hybrid Industrial: Jobs Emphasis, and Hybrid Industrial: Residential Emphasis. New Industry is defined as being employment tailored to $21^{\text {st }}$ century and creative industries such as digital technology, research and development, media, design, publishing, motion pictures, and broadcasting (L.A. City Planning Commission, 2017).

Beyond zoning, the plan also addresses Public Benefits, Urban Design Standards, and Streets in the corridor. The central theme to the plan is to encourage intensification while reducing the number of vehicle trips in the corridor. The plan goes so far as to require new projects to offer transit passes. For projects that incorporate residential, transit passes must be offered to anyone who doesn't opt to rent or buy parking, and the project must offer as many transit passes as there are parking spaces to their occupants. For projects that will have more than 50 employees, all 
employees must be offered a transit pass or equivalent reimbursement (L.A. City Planning Commission, 2017).

Ivy Station, also known as Ivy Station Transit Oriented Mixed Use Development, is located on a triangular site directly abutting Metro's Culver City Station (Fig. 4). This development is technically located within Culver City (an unannexed city located in southwest LA County), but it's northern property line is shared with the City of Los Angeles. The site was formerly comprised of light industry and commercial uses, along with a large surface parking lot. The development, which is currently under construction, is comprised of office, retail, restaurant, residential and hotel uses. The site will accommodate three buildings, two five storey and one six stories. According to site background documents drafted by Culver City, as of 2015 the site had been under study for almost 10 years as a TOD development site. This effort was jointly coordinated between Culver City, Metro, and the City of Los Angeles (Culver City, 2015). During those 10 years, several development scenarios had been studied, with this final proposal being chosen as it ensures a TOD that services the Metro station and reflects sound planning principles (Culver City, 2015). Ivy Station will set an important precedent for redevelopment in the Exposition Corridor, which is reflected in the comprehensive planning effort which was deployed for this project.

Martin Expo Town Center Project, is another large TOD project in the Expo Corridor. Martin Expo Town Centre is located at Metro's Bundy Station, the most westerly of the Expo Corridor stations (Fig. 4). This mixed-use development will incorporate residential, creative office, and commercial space into 5 buildings, ranging in height from six to ten stories. The site is currently occupied by a large car dealership, with a prominent frontage onto two main streets. The redevelopment will demolish all existing buildings on the site. The project intends on providing 
incentives to residents and employees to reduce driving and increase transit usage. They will employ travel demand management program measures which may include unbundled parking, transit pass discounts, car share and bike share programs (CAJA Environmental Services LLC, 2015). 

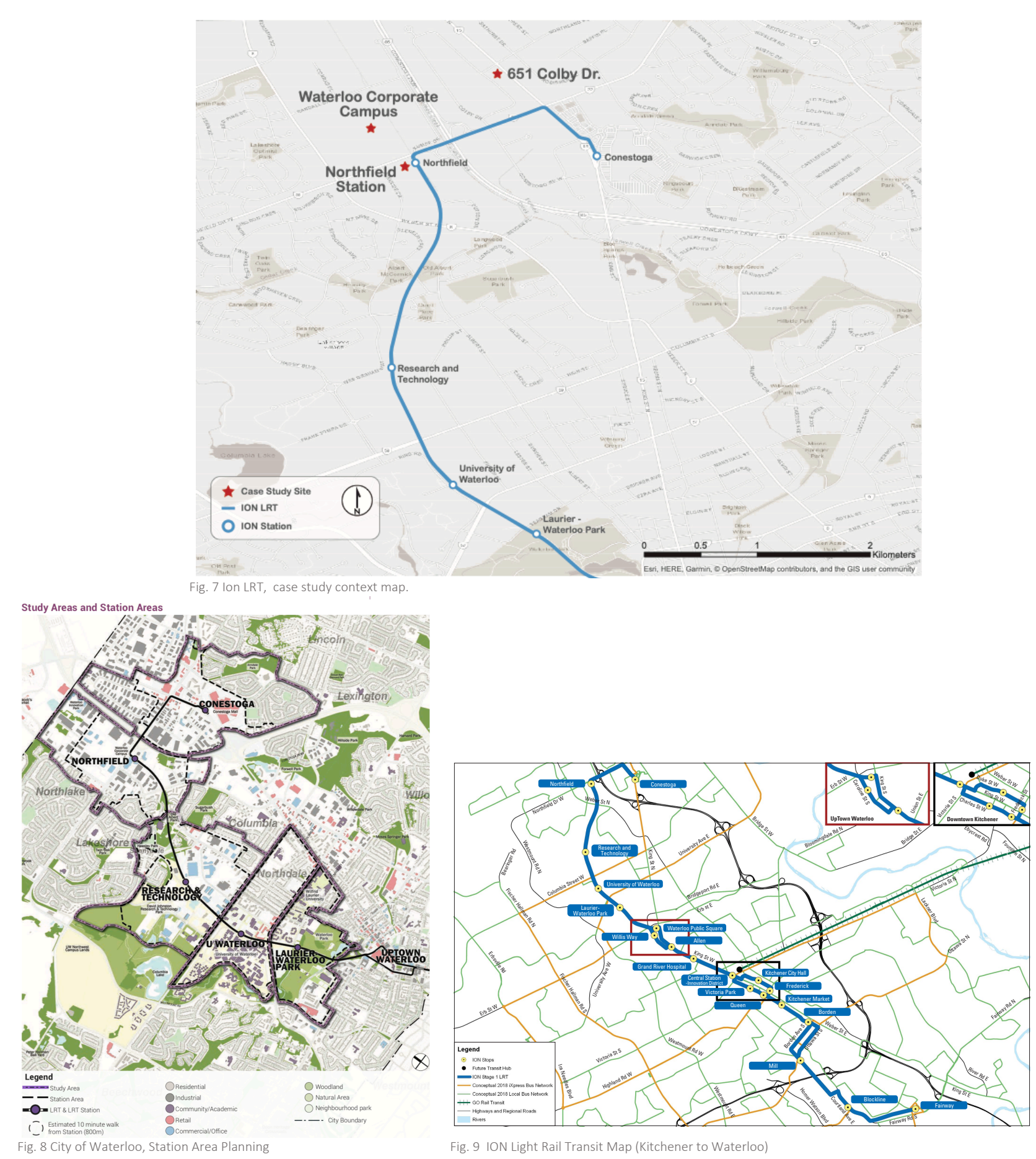

Fig. 9 ION Light Rail Transit Map (Kitchener to Waterloo)

\subsubsection{Ion Rapid Transit}

The Region of Waterloo's upcoming launch of the ION LRT is being heralded as a significant opportunity to connect employment lands, two universities, shopping districts, and established residential neighbourhoods in the City of Waterloo (Fig. 9). The City of Waterloo 
will be home to 8 of the 19 stations in the first phase of the ION LRT. To understand further the relationship between transportation and development in the ION LRT corridor, this section will look at two planning policies currently in place, as well as development that has been catalyzed by those policies.

Due to the potential for regeneration from this new piece of infrastructure, there are two pieces of policy which work to regenerate areas along the LRT in Waterloo. The first piece is the joint City and Region of Waterloo's Brownfields Community Improvement Plan (City of Waterloo, 2019). Due to Waterloo's history of industrial, manufacturing and commercial development, many sites throughout the City of Waterloo are considered to be brownfield sites. In order to help incentivise what has been traditionally passed over land, due to the costs of remediation, the city and region implemented a joint Tax Increment Grant (TIG) in 2013 (City of Waterloo, 2013). Current legislation only allows for TIGs in Ontario to be implemented through Community Improvement Plans, so the city created the City-Wide Brownfields Community Improvement Plan. In order to conform with the legislative framework, the CIP area is comprised of all lands within the City of Waterloo (City of Waterloo, 2013). The TIG is a grant that is equal in value up to the amount of the increased municipal property tax related to remediation of the site. This allows for property owners who remediated their contaminated lands to benefit from artificially lowered property tax in order to recoup their investment in the remediation.

The second policy piece in place is the City of Waterloo Station Area Planning: 5 Station Area Plans (City of Waterloo, 2017) (Fig. 8). The City of Waterloo has identified the five most northern stations on the ION LRT as "station areas" for further analysis and plans. The station 
areas are generally the walkable area around each of these stations ( $800 \mathrm{~m}$ or $10 \mathrm{mins})$. The purpose of these plans are to (City of Waterloo, 2015):

- Capitalize on and reinforce the station areas as centres of activity, with higher densities, a mix of uses and a high-quality public realm so that more people are able to live, work and access the services they need by transit;

- Support strong, vibrant and connected communities, helping to promote intensification around the station while also enhancing connections to and from stable residential neighbourhoods;

- [Acknowledge that] with over 33,000 jobs, numerous corporate headquarters and two world-class universities, these five station areas represent an unparalleled opportunity for economic development, supporting innovation and job growth within the City and Region.

While the aim of the Station Area Plans are to (City of Waterloo 2015):

- Encourage intensification around the future ION stations to increase transit ridership, encourage walking and cycling, and make more efficient use of the City's infrastructure and services;

- Promote community-building to support the unique character of each of the station areas and create attractive places for working, living, learning and recreation

- Stimulate new investment and promote economic development by encouraging job growth and commercial vitality;

- Support placemaking through public realm improvements, public art, new open spaces and enhanced amenity; and

- Create the basis for regulatory amendments, including updates to the Official Plan, Zoning By-law, and urban design guidelines

These aims all work together to take advantage of the strengths along the corridor, and the several vacant, underutilized, and contaminated lands found along it. The planning document has a strong push for significant transit-oriented growth, which also works with the city's plans to preserve their established neighbourhood which surround the corridor (City of Waterloo, 2015).

The two Stations Areas most likely to see brownfield remediation are Northfield and Conestoga (Fig. 7). This due to their location on either side of Conestoga Parkway within northern Waterloo's major employment area. This area has traditionally been home to industrial and manufacturing uses, and is currently an auto-oriented area. One development that has already occurred due to the LRT development is call Northfield Station (Fig. 7). Completed in 
2015, this office development directly adjacent to the future Northfield Station, this infill project involved the adaptive reuse of a 14,600sq.ft. industrial building, along with the construction of a three-storey 66,000sq.ft. Class A office building (Zehr Group, N.D.). To the northwest of Northfield Station is the currently developing Waterloo Corporate Campus, which is a 40 acre phased mixed-use redevelopment consisting of 135,000 sf of retail, 130,000 sf of loft office and a future $60,000 \mathrm{sf}$ data centre (Fig. 7). The first two of four phases are already complete, and include retail, office and the data centre (Triovest, N.D.) Another site worth examining, is the upcoming development in the Conestoga Station Area known as 651 Colby Dr. The site currently a two-storey commercial building on a brownfield site, and is $800 \mathrm{~m}$ from Conestoga Station (Fig. 7). The planning justification report for this property highlights the Provincial Policy Statement's promotion of redeveloping Brownfield sites, along with the Growth Plan 2017 policies toward redevelopment within transit corridors and station areas. The proposal is also inline with the City of Waterloo's official plan, and the Station Area plan. The site proposes to renovate the current structure into medical and dispensary uses, while building two new one storey commercial buildings on site (GSP, 2018). All of these developments work towards intensifying what is and will become a vibrant employment district, now supported by light rail transit. It is also significant to note that the ION LRT was recognised by the Canadian Brownfields Network's 2016 Brownie Awards, as winner of the "best large-scale project" award (CBN 2019). 


\subsection{Recommendations}

\subsubsection{Findings}

As was demonstrated in the three preceding case studies, there is a link between the implementation of light rail transit and brownfield redevelopment, but that link is not always clear. The three case studies were able to show LRT lines at different temporal scales of development and implementation. In Croydon, the LRT has been running for nearly 20 years, where in Los Angeles, the Expo Corridor has been running since 2016, and in Waterloo, it is yet to start operations.

Through the analysis of the case studies, a number of findings have been produced. The first being that each jurisdiction has a different emphasis on either Brownfield or Transportation. In Croydon, and London in general, there is a much more concerted effort to redevelop brownfield lands. This can be viewed as smart growth in the way that Greenberg et. al (2001), categorised it. The Croydon Opportunity Area is a perfect example of smart growth defined as the clustering of people and their activities in central areas or along corridors which are already developed, thus avoiding greenfield development. As demonstrated through the planning reports, redeveloping underutilized brownfields was often the first consideration, and while transportation was relevant to local planning support, the emphasis on LRT in specific was not there. It is plain to see that the LRT in central Croydon is an important piece of infrastructure, and that there are provision for developers to help fund its expansion, it seems as though the connections to the heavy rail stations (West and east Croydon), were equally important.

In Los Angeles on the Expo Corridor, the link between brownfield and transportation is more clear, even if slightly veiled. This case study fits with the categorisation of the associated relationship between brownfield redevelopment and transportation investment described by 
Amekudzi and Fomunung (2004). They state that for any regeneration to occur, the simultaneous development of transit is necessary. It is clear to see that the Exposition Corridor Transit Neighbourhood Plan goals align with the multiple benefits of job creation, tax base enhancement, environmental remediation, and infrastructural renewal that Amekudzi and Fomunung describe. The authors concluded that transportation improvement projects can be used proactively to incentivize brownfield redevelopment, and that this is desirable due to the economic, social, and environmental benefits that come with brownfield regeneration. While most sites that are available for redevelopment are former industrial/manufacturing, parking lots, and car dealerships, the word 'Brownfield' is not mentioned once in the Exposition Corridor Transit Neighbourhood Plan. This could be because the plan would like to see ' $21^{\text {st }}$ century' industry take root in the corridor and labeling it as contaminated land isn't a great economic selling point.

In Waterloo, the emphasis is again on LRT over brownfield. The 5 Station Area plans make a compelling case for redevelopment within the corridor, and aligns with many of the benefits of LRT as described by Ferbrache and Knowles (2016). The authors point out that effective routes and connections of an LRT system can improve urban flows, create better accessibility and increase the quality of urban centres, which are all desired in the 5 Station Area plans. The waterloo case study also relates to Olsen's (2014) observations of how LRTs often are used to form the backbone of a transportation network, in this case Grand Rapid Transit. This in turn leads to intensified and sustainable urban development, and increased options for transportation infrastructure. What is missing from the 5 Station Area plans are any mention of the word 'brownfield'. In the 292 page Station Area plan, there is not one mention of the word 
'brownfield', or 'contaminated'. The word 'underutilized' is used repeatedly when referring to what would be considered brownfield sites.

All three case studies, contain elements of Transit Oriented Development as described by Susuki et. al. (2013), where a holistic approach of building well-integrated transit and land development creates spaces that require less travel by automobiles, are encouraging of active transportation (walking biking), are attractive for working and living, and reduce local pollution and greenhouse gases.

\subsubsection{Limitations of Case Studies}

There were several limitations to in the ability to fully investigate the research questions set out in the paper. These limitations were geographic, informational, and institutional.

Access to information at a proper geography was the biggest limitation due to availability of information remotely in each jurisdiction. While Official Plans and Policies where easily accessed in each case study, planning reports themselves were very hard access. After a concerted effort to search through Croydon's planning database, all planning documents were located. The difficulty was how to find them. Some documents were under the name of a former on-site building, while some were still labelled with an early marketing name for the site. In Los Angeles, the Department of City Planning only allows for documents to be searched by case number. There is no master list of case numbers or any keyword search options for finding documents. The planning document for Ivy Station was located through Culver City's planning portal, not the City of Los Angeles. It is probable that one would have to visit the Planning Department in person in order to identify case numbers, and to obtain further information on development applications. In Waterloo, it was also quite difficult to find planning reports 
through the city's online portal. Of the three properties mentioned, only one was available online. One frustrating aspect that was common to all three case studies, was there is no centralized development application database or map, such as the one found in the City of Toronto (CoT, 1998-2019). Moreover, geospatial data of any kind was not easily accessible for these case studies. Croydon was the only jurisdiction with brownfield geospatial data, while waterloo was the only jurisdiction to have publicly accessible work permit data. This made it impossible for a standardized analysis of geospatial data in the case studies.

This paper had set out to conduct interviews with professionals, in order to obtain a better understanding of the processes behind LRT implementation. The issue with this project was that no one qualified to answer these questions were available or accessible. Several messages were sent to the various transportation agencies, planning departments, and city councils. The only messages that were responded to were through customer service channels via social media. In Croydon, it was made known that no one on Council that oversaw the implementation of Tramlink or the buyback of Tramlink were still on Council. It was also stated that no one from TfL would be able to answer questions as they did not build the project. In LA, there was a similar experience to Croydon. In Waterloo, emails went unanswered. The common thread as to why no one was available to answer questions about these projects was due to them being developed as P3s. Tramlink was built by a private consortium which disbanded. The Exposition Line was also built by a private consortium which disbanded as soon as the line was operational. This leads to the question of if so many resources and public dollars are entrusted in private companies to build these mega infrastructure projects, why is there no provision for insuring the gained institutional knowledge is preserved? When infrastructure projects were built purely by the public sector by public agencies, it would be assumed that the professionals who worked on 
those projects would remain in the public service, or at the very least, all the internal documents would remain in the public domain for future reference.

\subsubsection{Conclusion}

Throughout this paper, three case studies were used to take an in-depth look into the relationship between light rail transit and the redevelopment/regeneration of urban brownfield sites. In specific, this paper set out to answer a primary research question, and two secondary questions:

- What are the Impacts of Light Rail Transit on the Regeneration of Urban Brownfield Areas?

- How Does Transportation Infrastructure, Urban Redevelopment, and Sustainable Development Impact the Decision to Implement Light Rail Transit and Regenerate Urban Brownfield Areas?

- How Do Stakeholders, Local Economies, Social Fabrics, and Environments Impact These Decisions and How are They Affected by Them?

Through this paper's policy, planning, and development analysis, an answer to the first two questions was attempted. The third research question was to be informed by semi-structured professional interviews that were not conducted. The "financing LRT" section of this paper can be viewed as an insight into the stakeholder and local economy lenses, but without the professional opinions that were sought by this paper, the final question is inconclusive. We can conclude from the case studies, that there is a positive impact between the implementation of light rail transit and the regeneration of urban brownfield areas. The second question is more nuanced, and as we can see from the case studies, jurisdictional priorities influence the importance and role of transportation infrastructure, urban redevelopment, and sustainable development. Croydon demonstrated a strong priority towards sustainable development of brownfields, where Los Angeles demonstrated transportation infrastructure and urban redevelopment as it's top priority in relation to light rail transit. The same could be said for 
Waterloo. In conclusion, a concerted effort was made to answer the research questions laid out in the introduction to this paper. The realities of geography, information, and institutional frameworks and systems, made for several challenges and limitations not fully foreseen at the onset of this paper.

\subsubsection{Recommendations}

While a positive impact has been found in respect to the implementation of light rail transit on urban brownfield regeneration, further analysis is necessary. First, if such an investment is to be undertaken through a private-public partnership, some means of maintaining institutionalised knowledge should be preserved. As demonstrated through the case study early methodology, once a project was complete, it was very difficult to obtain information and best practices from this process. A centralised tracking of development outcomes tied to transit investment would be beneficial to not only the jurisdiction making the investment, but also to other jurisdictions considering such an investment. This could be accomplished by following the policy recommendation that Amekudzi and Fomunung (2004) make of developing brownfield/transportation organizational infrastructure (formal relationships between brownfield redevelopment agencies and transportation planning agencies) to coordinate brownfields and transportation plans. It might also be logical to move away from the term brownfield, and instead use the terms underutilized or post-industrial, as found in the cases of Los Angeles and Waterloo. This would perhaps lift a social stigma against the redevelopment of these lands.

Second, this paper recommends that jurisdictions interested in this form of infrastructure investment prioritize the simultaneous development of transportation infrastructure and brownfield regeneration, as it appears to be a most effective method. Keeping a wholistic 
approach to transportation and land use planning, can help to accelerate the return on investment. Again, this ties to observations made by Amekudzi and Fomunung (2004) that the benefits of simultaneous development of transportation improvement projects and brownfield redevelopment were multiple, and provide job creation, tax base enhancement, environmental remediation, and infrastructural renewal. The tax base enhancements could be used for land value capture, and in turn, be used as a way to finance the transportation improvement projects. The final recommendation would be to pursue semi-structured interviews with professionals involved in these projects. These interviews are warranted and would be greatly beneficial to any further research or decisions to implement light rail transit projects. 


\subsection{References}

- AECOM. (2005). Synthesis of public private partnership projects for roads, bridges and tunnels from around the world-1985-2005. Washington DC: U.S. Department of

Transportation, Federal Highway Administration. https://rosap.ntl.bts.gov/view/dot/5529

- Amekudzi, A., \& Fomunung, I. (2004). Integrating brownfields redevelopment with transportation planning. Journal of Urban Planning and Development, 130(4), 204-212. 10.1061/(ASCE)0733-9488(2004)130:4(204)

- Barbu, D. (2013). Studies and researches regarding the urban policies impact on land valuation. Aestimum, , 169-181. doi:10.13128/Aestimum-13131

- Berkley Homes (2007). Wellesley Square Croydon, Environmental Statement Main Report. Peter Radmall Associates. https://publicaccess3.croydon.gov.uk/onlineapplications/files/EA4E484763EBA09DC6CCE574E70B41CE/pdf/07 01057 PWellesley Main Report Final - Environmental-1134193.pdf

- Bird, R. M., \& Slack, E. (Eds.). (2017). Financing infrastructure : who should pay?. Retrieved from https://ebookcentral-proquest-com.ezproxy.lib.ryerson.ca

- Canadian Council for Public-Private Partnerships (2005-16). Definitions and Models. http://www.pppcouncil.ca/web/Knowledge Centre/What are P3s /Definitions Models/ web/P3 Knowledge Centre/About P3s/Definitions_Models.aspx?hkey=79b9874d-449846b1-929f-37ce461ab4bc

- $\quad$ CBN (2019). 2016 Brownie Award Winners. Canadian Brownfields Network. https://www.canadianbrownfieldsnetwork.ca/brownfield-awards/brownies/2016brownies-winners

- Chapman, J. (2017). Value capture taxation as an infrastructure funding technique. Public Works Management \& Policy, 22(1), 31-37. doi:10.1177/1087724X16670395

- City of Ottawa (2018). O Train, Confederation Line. https://www.ligneconfederationline.ca

- City of Toronto (1998-2019). Development Projects. City of Toronto. http://app.toronto.ca/DevelopmentApplications/mapSearchSetup.do?action=init

- City of Toronto (1998-2019). Official Plan. City of Toronto. https://www.toronto.ca/citygovernment/planning-development/official-plan-guidelines/official-plan/

- City of Waterloo (2013). City-Wide Brownfields Community Improvement Plan. City of Waterloo. https://www.waterloo.ca/en/government/resources/Documents/EconomicDevelopment/Brownfiels-Community-Improvement-Plan.pdf

- City of Waterloo (2017). 5 Station Area Plans. City of Waterloo. https://www.waterloo.ca/en/government/resources/Documents/Cityadministration/Rapidtransit-station-area-plans.pdf

- City of Waterloo (2019). Tax increment grants. City of Waterloo. https://www.waterloo.ca/en/government/tax-increment-grants.aspx

- Croydon (2019). SPDs including the opportunity area planning framework. Croydon Council.

https://www.croydon.gov.uk/planningandregeneration/framework/localplan/spdandoapf

- Croydon Limited Partnership (2016). Planning Statement Whitgift Centre. Quod. https://publicaccess3.croydon.gov.uk/online- 
applications/files/CF9EAA8440C88C4E6E3849B06302D639/pdf/12 02542 P-

Planning_Statement__ FINAL-445161.pdf

- Culver City Planning Division (2015). Ivy Station TOD Mixed-Use. Culver City. https://www.culvercity.org/Home/ShowDocument?id=2044

- Deloitte Research. (2006). Closing the infrastructure gap: The role of public-private partnerships. London: Deloitte Development LLP.

https://www2.deloitte.com/content/dam/Deloitte/ie/Documents/Finance/Corporate\%20Fi nance/2006 closing_infrastructure gap deloitte ireland.pdf

- FCM (2015). Tax Increment Financing. Federation of Canadian Municipalities. https://fcm.ca/home/programs/partners-for-climate-protection/alternative-financingmechanisms/tax-increment-financing.htm

- FCM (2018). Infrastructure. Federation of Canadian Municipalities. https://fcm.ca/home/issues/infrastructure.htm

- Ferbrache, F., \& Knowles, R. (2016). Generating opportunities for city sustainability through investments in light rail systems: Introduction to the special section on light rail and urban sustainability. Journal of Transport Geography, 54, 369-372. 10.1016/j.jtrangeo.2016.06.004

- Grandlinq Contractors (2014). About Grandlinq. Grandlinq Contractors. http://www.rideion.ca/about-grandlinq.html

- Greenberg, M., Lowrie, K., Mayer, H., Miller, K. T., \& Solitare, L. (2001). Brownfield redevelopment as a smart growth option in the united states. The Environmentalist, 21(2), 129-143. doi:10.1023/A:1010684411938

- Gwilliam, K. M., \& World Bank. (2002). Cities on the move: A world bank urban transport strategy review. United States: World Bank.10.1596/0-8213-5148-6

- Haider, M., \& Donaldson, L. (2016). Can Tax Increment Financing Support Transportation Infrastructure Investment?. Institute on Municipal Finance and Governance. ISBN 978-0-7727-0955-4

- Hong, A., Boarnet, M. G., \& Houston, D. (2016). New light rail transit and active travel: A longitudinal study. Transportation Research Part A: Policy and Practice, 92, 131-144. 10.1016/j.tra.2016.07.005

- Howard Holdings Plc (2007). Attitude 25, Fairfield Road, Croydon, Planning Statement. Howard Holdings Plc. https://publicaccess3.croydon.gov.uk/onlineapplications/files/11330A6FA2FD983BE1FAFA406945D9AB/pdf/07 01387 PPlanning_statement-1041348.pdf

- Infrastructure Ontario (N.D.). Eglinton Crosstown LRT. Infrastructure Ontario http://www.infrastructureontario.ca/Eglinton-Crosstown-LRT/

- Infrastructure Ontario (N.D.). Region of Waterloo's Light Rail Transit System. Infrastructure Ontario. http://www.infrastructureontario.ca/Region-of-Waterloos-LightRail-Transit-System/

- Johnson, K. L., Dixson, C. E., \& Tochterman, S. P. (2002). Brownfield redevelopment and transportation planning in the philadelphia region. Institute of Transportation Engineers. ITE Journal, 72(7), 26.

- Ko, K., \& Cao, X. (2013). The impact of Hiawatha light rail on commercial and industrial property values in Minneapolis. Journal of Public Transportation, 16(1), 4766. 
- LA City Clerk Connect (2018). Council File: 18-0437. City of Los Angeles. https://cityclerk.lacity.org/lacityclerkconnect/index.cfm?fa=ccfi.viewrecord\&cfnumber $=1$ $\underline{8-0437}$

- LA Department of City Planning (2015). Final Environmental Impact Report. West Los Angeles Community Plan Area. Martin Expo Town Centre Project. City of Los Angeles. http://planning.lacity.org/eir/martinexpotowncenter/feir/FEIR\%20Sections/FEIR\%20Mar tin\%20Expo\%20Town\%20Center.pdf

- LA Merto (2017-2018). Expo Line Media Centre. Metro. https://www.metro.net/news/media-kits/expo-media/

- Li, B., Akintoye, A., Edwards, P. J., \& Hardcastle, C. (2005). Critical success factors for $\mathrm{PPP} / \mathrm{PFI}$ projects in the UK construction industry. Construction Management and Economics, 23(5), 459-471. doi:10.1080/01446190500041537

- London Borough of Croydon (2018). Croydon Local Plan 2018. Croydon Council, London Borough of Croydon. https://www.croydon.gov.uk/planningandregeneration/framework/localplan/clppolicies

- London Borough of Croydon (2018). Deed of Agreement. Pinsent Masons. https://publicaccess3.croydon.gov.uk/onlineapplications/files/1C951A05D3D2BA24859ADDB67D3C7021/pdf/16_05418_OUTS106_AGREEMENT - WHITEGIFT_SHOPPING_CENTRE_-20.04.2018_PART 1-2270035.pdf

- Los Angeles Department of City Planning (2017). Exposition Corridor Transit Neighborhood Plan. Los Angeles Department of City Planning. http://clkrep.lacity.org/onlinedocs/2018/18-0437_misc_1_05-17-2018.pdf

- Los Angeles Times (2009). Mapping L.A., Regions, The Westside. Los Angeles Times. http://maps.latimes.com/neighborhoods/region/westside/

- Mayor of London (2019). Croydon Opportunity Area. Greater London Authority. https://www.london.gov.uk/what-we-do/planning/implementing-londonplan/opportunity-areas/opportunity-areas/croydon-opportunity

- Mayor of London (2019). London Opportunity Areas. Greater London Authority. https://www.london.gov.uk/what-we-do/planning/implementing-londonplan/opportunity-areas/what-are-opportunity-areas

- Mayor of London (2019). London Plan Overview and Introduction. Greater London Authority. https://www.london.gov.uk/what-we-do/planning/london-plan/current-londonplan/london-plan-overview-and-introduction

- Mayor of London (2019). What is the New London Plan?. Greater London Authority. https://www.london.gov.uk/what-we-do/planning/london-plan/new-london-plan/whatnew-london-plan

- Merriman, D. (2018). Improving Tax Increment Financing (TIF) for Economic Development. Policy Focus Report, Lincoln Institute of Land Policy. ISBN 978-155844-378-5 (PDF)

- Metro (2017-18). Public-Private Partnerships for Metro Transportation Projects. Metro. https://www.metro.net/projects/public private partnerships/

- Metro (2017-2018). Expo Line Media Centre. Metro. https://www.metro.net/news/mediakits/expo-media/

- Metro (2017-2018). Proposition A \& C and Measure R Sales Taxes. Metro. https://www.metro.net/about/financebudget/taxes/ 
- Metro (2017-2018). Transportation Funding. Metro. https://www.metro.net/projects/funding/

- Metro (2017). Metro Funding Sources Guide. Los Angeles County Metropolitan Transportation Authority. https://media.metro.net/about_us/finance/images/2017_funding_sources_guide.pdf

- Olesen, M. (2014). Framing light rail projects - case studies from Bergen, Angers and Bern. Case Studies on Transport Policy, 2(1), 10-19. 10.1016/j.cstp.2013.12.002

- Ontario (2008-2019). Places to Grow Act, 2005. Queen's Printer for Ontario. https://www.placestogrow.ca/index.php?option=com content\&task=view\&id=1\&Itemid $\underline{\underline{P}}$

- Planning Act. RSO 1990, c. P13, s 37. https://www.ontario.ca/laws/statute/90p13\#BK59

- Region of Waterloo (2017). ION light rail. Grand River Transit. http://www.grt.ca/en/ion-light-rail.aspx

- Region of Waterloo (2017). ION light rail. Grand River Transit. http://www.grt.ca/en/ion-light-rail.aspx

- Region of Waterloo (N.D.). The Story of Rapid Transit in Waterloo Region. Region of Waterloo. https://rapidtransit.regionofwaterloo.ca/en/resourcesGeneral/IONStory_final.pdf

- Region of Waterloo and Ontario Infrastructure and Lands Corporation (2013). Project Agreement (Executive Version), Region of Waterloo Stage 1. Queen's printer for Ontario. http://rapidtransit.regionofwaterloo.ca/en/multimedialibrary/resources/ProjectAgreement. pdf

- Rise Commercial Group (2018). Planning Justification Report. 651 Colby Drive. GSP Group Inc. https://www.waterloo.ca/en/government/resources/Documents/Zone-ChangeApplications/651-Colby-Dr/651-Colby-Dr-planning-justification-report.pdf

- Rizzo, E., Pesce, M., Pizzol, L., Alexandrescu, F. M., Giubilato, E., Critto, A., . . . Bartke, S. (2015). Brownfield regeneration in europe: Identifying stakeholder perceptions, concerns, attitudes and information needs. Land use Policy, 48, 437-453. 0.1016/j.landusepol.2015.06.012

- Ruffilli, D. C., \& Canada. Parliamentary Information and Research Service. (2010). Federal support for bus rapid transit and light rail transit systems in canada Library of Parliament.

- Siemiatycki, M. (2009). Delivering transportation infrastructure through public-private partnerships: Planning concerns. Journal of the American Planning Association, 76(1), 43. doi:10.1080/01944360903329295

- Statistics Canada (2018). Infrastructure Statistics Hub. https://www150.statcan.gc.ca/n1/pub/71-607-x/2018013/ic2-eng.htm

- Statistics Canada. 2017. Waterloo, RM [Census division], Ontario and Ontario [Province] (table). Census Profile. 2016 Census. Statistics Canada Catalogue no. 98-316X2016001. Ottawa. Released November 29, 2017. http://www12.statcan.gc.ca/census-recensement/2016/dp-pd/prof/index.cfm?Lang=E

- Suzuki, H., Cervero, R., \& Iuchi, K. (2013). Transforming cities with transit: Transit and land-use integration for sustainable urban development World Bank.

- Toronto Transit Commission (2017). Toronto-York Spadina Subway Extension. https://www.ttc.ca/Spadina/About_the_Project/FAQ.jsp 
- Transport for London (2008). Transport for London takes over Tramlink services. Mayor of London, Tfl. https://tfl.gov.uk/info-for/media/press-releases/2008/june/transport-forlondon-takes-over-tramlink-services

- Transport for London (2008/09). Annual Report and Statement of Accounts 2008/09. Mayor of London, Tfl. http://content.tfl.gov.uk/annual-report-and-statement-of-accounts2008-09.pdf

- Transport for London (N.D.). London Trams. Mayor of London, TfL. https://tfl.gov.uk/corporate/about-tfl/what-we-do/london-trams?intcmp=2647

- Transport for London (N.D.). London Trams. Mayor of London, TfL. https://tfl.gov.uk/corporate/about-tfl/what-we-do/london-trams?intcmp=2647

- Tremblay-Racicot, F. R., \& Mercier, J. (2014). Integrating transportation and land use planning at the metropolitan level in north america: Multilevel governance in toronto and chicago. URBE - Revista Brasileira De Gestão Urbana, 6(541), 184-200. 10.7213/urbe.06.002.SE04

- Triovest (n.d.) Waterloo Corporate Campus. Triovest. https://leasing.triovest.com/building.php?building=3407206640805146038

- United Nations (N.D.). Sustainable Development Goals. UN Web Services Section, Department of Public Information, United Nations. http://www.un.org/sustainabledevelopment/sustainable-development-goals/

- United States Environmental Protection Agency (2018). Overview of the Brownfields Program. United States Environmental Protection Agency. https://www.epa.gov/brownfields/overview-brownfields-program

- USDOT Federal Highway Administration (2017). Public-Private Partnerships (P3s). Center for Innovative Finance Support. https://www.fhwa.dot.gov/ipd/pdfs/fact_sheets/techtools_P3_options.pdf

- Vectordesign (2007). Sustainability Report at Altitude 25, Fairfield Road. Vectordesign. https://publicaccess3.croydon.gov.uk/onlineapplications/files/EB8D3B403447428EFB80BD5F870570F4/pdf/07 01387 PSustainability Report-653515.pdf

- Wang, L., Fang, L., \& Hipel, K. W. (2011). Negotiation over costs and benefits in brownfield redevelopment. Group Decision and Negotiation, 20(4), 509-524. 10.1007/s10726-009-9179-5

- Workspace Management Limited (2015). Planning Statement Lombard House. Savillis UK Limited. https://publicaccess3.croydon.gov.uk/onlineapplications/files/4FF4895EAC61E8DB763BA7E24AEC5235/pdf/15_01236_P_ Planning_Statement-716564.pdf

- Zehr (n.d.) Northfield Station. Zehr Group Inc. https://www.zehrgroup.ca/project/northfield-station/ 